\title{
An Investigation of Preservice Teachers' Self-Efficacy for Teaching with Technology
}

\author{
Rebecca M. Giles ${ }^{1} \&$ Andrea M. Kent ${ }^{1}$ \\ ${ }^{1}$ College of Education, University of South Alabama, Mobile, AL, USA \\ Correspondence: Rebecca M. Giles, Department of Leadership and Teacher Education, College of Education, \\ University of South Alabama, UCOM 3100, Mobile, AL, USA. Tel: 1-251-380-2899. E-mail: \\ rgiles@usouthal.edu
}

Received: January 25, 2016

Accepted: January 29, $2016 \quad$ Online Published: February 26, 2016

doi:10.20849/aes.v1i1.19

URL: http://dx.doi.org/10.20849/aes.v1i1.19

\begin{abstract}
Self-efficacy has been persistently cited as a major component in understanding how frequently and successfully individuals use technology. Preservice teachers' technology self-efficacy is a creditable indicator of graduates' likelihood to use instructional technology throughout their careers; thus, it is imperative that new teachers graduate with a high sense of self-efficacy regarding their abilities to use technology as an effective teaching tool. The purpose of this study was to determine preservice teachers' self-efficacy beliefs related to integrating technology into instruction. Elementary preservice teachers $(\mathrm{n}=28)$ from a single university completed a Likert-type survey using a forced choice scale with six points. Responses to the 5-item survey were converted to numerical data, and the research question was examined using descriptive statistics. Data indicated that almost all $(93 \%)$ of the participants incorporated technology into the lessons they taught with the majority $(68 \%)$ of participants reporting a high level of confidence in their ability to select and utilize technology in teaching. Further, $89 \%$ of the participants felt they could integrate technology across the curriculum with $80 \%$ indicating they were capable of determining the why, when, and how to do so most of the time.
\end{abstract}

Keywords: efficacy, preservice teachers, teacher preparation, technology

\section{Introduction}

Teaching self-efficacy has been shown to impact teachers' behavior. Along with knowledge, positive self-efficacy is a necessary requirement for teachers' effective integration of instructional technology (Moore-Hayes, 2011). Further, teachers' potential to affect students' beliefs and values, leads to the possibility that teachers will strongly affect students' attitudes regarding the use of computers and technology for educational purposes (Christensen, 1998). Since the efficacy of experienced teachers is nearly impossible to change (Hoy, 2000), preservice teachers' technology self-efficacy is a creditable indicator of graduates likelihood to use instructional technology throughout their careers.

\section{Background}

Students' acquisition of a high-level of technological skill and ability is considered a basic part of the $21^{\text {st }}$ century curriculum, equivalent in importance to reading and writing (Unesco, 2000). Thus, current educators are obligated to use technology as a teaching tool (Haydn \& Barton, 2008). Across the United States school districts are making technology integration a priority and, as a result, investing significantly in both equipment and professional development for instructional technology (Lever-Duffy \& McDonald, 2011). Regardless of improved technological access as well as increased training opportunities, technology remains underutilized as teachers fail to meet expectations for using technology in their teaching (Roblyer \& Doering, 2010).

Integrating technology into teaching is among the greatest challenges facing today's teachers (Cennamo, Ross, \& Ertmer, 2010; Clausen, 2007; Wang, Ertmer, \& Newby, 2004). Research (Zhao \& Frank, 2003) suggests that teachers are receptive to infusing technology into their teaching as a way to improve instruction and are often expected to serve as catalyst for change regarding the integration of technology in schools (Zhao, Tan, \& Mishra, 2001). For a variety of reasons, however, many teachers have not fully integrated technology into their teaching. Factors found to have an influence on teachers' use of technology range from the school's physical facility (Ertmer, $2005)$ to teachers' attitudes towards computer use (Teo, 2009, 2010). Self-efficacy has repeatedly been reported as 
a major component in understanding the frequency and success with which individuals use technology (Eachus \& Cassidy, 2002; Sure, 2009). As the National Council of Teachers of English (2013) state in their literacy in the $21^{\text {st }}$ century definition, a literate person must be able to develop proficiency with technological tools in a global community, using multiple streams of simultaneous information, think critically about multi-media text, while maintaining ethical standards required by these complex environments. It can be postulated that teachers' beliefs regarding their capacity to work effectively with technology in general are directly related to their integration of technology in teaching. Consequently, the measurement of technology self-efficacy is a useful indicator of teacher education programs' effectiveness in preparing graduates to use instructional technology (Albion, 1999).

\subsection{Teacher Efficacy}

Efficacy beliefs have long been associated with the work of psychologist Albert Bandura (1977), who defined efficacy as intellectual activity leading to an individual's development of beliefs about his or her ability to achieve a certain degree of accomplishment. Bandura advocated that people develop specific beliefs concerning their coping ability to change what he called "self-efficacy" and defined as "beliefs in one's capabilities to organize and execute the courses of action required to produce given attainments" (Bandura, 1997, p. 3). An individual's high level of self-efficacy may lead to accomplishing tasks that exceed his or her capabilities, while low self-efficacy might result in the underestimation of one's abilities, thus, leading to underachievement (Bandura, 1982). Consequently, the likelihood that a particular task will be completed successfully is amplified by an individual's perception of his or her capabilities to effectively perform the task (Sure, 2009). Since behaviors are usually guided by perceptions of self-efficacy rather than true capabilities (Pajares, 2002), beliefs are a stronger predictor of behavior than knowledge in determining an individual's approach to a task or problem (Pajares, 1992). The strong effect of one's confidence to perform specific tasks on behavior has made self-efficacy of particular interest to educational researchers (Albion, 1999).

The value and power of teachers' sense of efficacy has been well established in the literature (Knoblauch \& Hoy, 2008). Teachers who have confidence in their own teaching abilities (i.e., a greater sense of self-efficacy) provide a greater academic focus in the classroom (Gibson \& Dembo, 1984), are more likely to try innovative practices (Sparks, 1988), and engage in a greater degree of ongoing staff development programs (Gersten, Chard, \& Baker, 2000) than their peers with lower perceptions of their ability to influence student learning. Additionally, a strong sense of efficacy "can pay dividends of higher motivation, greater effort, persistence and resilience" (Tschannen-Moran, Hoy, \& Hoy, 1998, p. 238). Further, teacher self-efficacy is directly linked to students' performance (Dembo \& Gibson, 1985; Woolfolk \& Hoy, 1990) and has been identified as a powerful influence on teachers' overall effectiveness (Pendergast, Garvis, \& Keogh, 2011).

Graham, Harris, Fink, and MacArthur (2001) assert that teachers' efficacy is "one of the few teacher characteristics that reliably predicts teacher practice and student outcomes" (p. 178). Since self-efficacy relates to an individual's perceptions regarding distinct behaviors, it is considered to be situation specific or domain sensitive (Sure, 2009). As a result, multiple instruments have been developed to measure the efficacy of pre- and inservice teachers in various domains. Self-efficacy in the area of computer use and technology integration has been of particular interest in recent years (Albion, 1999; Christensen, 1998; Curts, Tanguma, \& Peña, 2008; Gökçek, Güneş, \& Gençtürk, 2013; Jimoyiannis \& Komis, 2006; Miles, 2013; Moore-Hayes, 2011, Oliver \& Shapiro, 1993; Wang et al., 2004).

\subsection{Technology Efficacy}

Teachers constitute the critical factor regarding technology integration in the schools (Jimoyiannis \& Komis, 2006). According to Clausen (2007), technology integration is often a challenge as preservice teachers transition from their teacher education programs to become first year teachers. Technical knowledge and skill are only two of the many aspects influencing teachers' successful integration of in teaching (Miles, 2013). While comfort using computers may influence teachers' use of technology in teaching (Albion, 2001), Oliver and Shapiro (1993) found that providing new teachers with professional development related to computers as a personal tool did not positively influence their use of computers for instruction. These results are not totally surprising, since numerous factors beyond technical knowledge and skill impact teachers' success at integrating technology into their teaching (Albion, 1999). These factors include time to integrate curriculum, home access to the Internet (Curts et al., 2008), amount of training (Watson, 2006), vicarious experience with technology (Wang et al., 2004), and level of confidence regarding computer proficieny (Ropp, 1999). Teachers' use of computers for teaching has been correlated with their belief in their ability to do so (Marcinkiewicz, 1994; Paraskeva, Bouta, \& Papagianni, 2008). In order for teachers to use technology for instructional purposes, they must first view themselves as 
self-efficacious in using computers (Ropp, 1999) making a strong sense of computer self-efficacy a necessary condition for positive self-efficacy regarding the use of computers in their teaching (Albion, 1999).

In fact, the greatest barriers to successful technology integration in instruction appear to be those related to teachers' efficacy-beliefs (Clausen, 2007; Schrum, Shelly, \& Miller, 2008). In a study conducted by Moore-Hayes (2011), she reported that both pre- and inservice teacher participants perceived themselves as "less than adequately prepared" to effectively use technology for instructional purposes (p. 8). Wang, et al., (2004) correlated teachers' low self-efficacy toward their integration of technology to a limited assurance in their ability to use computers in teaching. Similarly, several studies (Albion, 1996; Downes, 1993; Handler, 1993; Summers, 1990) acknowledged preservice and new teachers' lack of confidence regarding the use of computers for teaching as contributing to their degree computer use. While greater self-efficacy beliefs for teaching with technology are not an automatic guarantee that technology use will increase, they are an essential prerequisite for integrating technology into instruction (Wang, et al., 2004).

\subsection{Preparing Preservice Teachers to Integrate Technology}

Preservice teachers must be taught to effectively use technology as a teaching tool by integrating technology throughout the preservice curriculum (Groth, Dunlap, \& Kidd, 2007). Technology has changed the traditional instructional model to an information-age conversational model of learning where the learner is actively engaged in co-creating meaning and knowledge with peers (Romiszowski \& Ravitz, 1997). When technology is introduced, the role of the teacher often shifts to that of facilitator (Watson, 2006). Technology integration in the preservice curriculum must go beyond stand alone technology classes. Infusing instructional technology into all method courses in needed to give preservice candidates the confidence to use technology in their teaching (Pope, Hare \& Howard, 2002).

University faculty play a critical role in preservice teachers technology efficacy. Technology should not only be integrated into the coursework, but it is important for faculty to model technology in the classroom (Pope et al., 2005). A study by Bitner and Bitner (2002) emphasized the importance of faculty supporting preservice teachers. Faculty need to be supportive when preservice teachers need help with learning computer basics, including offering training, to moving to more complex technologies and their implementation. Another area of support preservice teachers need from faculty is the fear of changing, fluid emerging technologies (Bitner \& Bitner, 2002). The evolution of technology often brings uncertainty and new teachers must be willing to embrace change for the betterment of their instruction and the impact on student learning.

Supervising teachers during internships are another important model for preservice teachers and play an important role in preservice teacher's technology efficacy (Pope et al., 2005). Research by Groth et al., (2007) emphasizes the challenge, but importance of preservice teachers integrating technology into internship experiences. By universities integrating technology throughout the preservice curriculum, the skills and technology efficacy preservice teachers gain through university coursework and internship experience will foster the integration of technology in their future classrooms (Groth et al., 2007).

\section{Purpose and Significance of Study}

Teaching self-efficacy has been shown to impact teachers' behavior, particularly in regard to technology integration (Wang et al., 2004). Teachers have the potential to impact students' feelings and attitudes based on their personal affect regarding the use of technology for teaching and learning (Christensen, 1998). The purpose of this study was to obtain and measure elementary preservice teachers' self-efficacy beliefs regarding technology integration for instruction. Teacher's positive self-efficacy related to technology integration has both immediate and long term implications, making this study's findings pertinent to teacher educators, school administrators, certification and licensing boards, and those involved in the mentoring and induction of new teachers. The observation that teacher education programs play an important role in the development of teacher candidates' self-efficacy and identity (Pendergast et al., 2011) makes the topic of preservice teacher technology integration efficacy of particular importance to teacher educators.

\section{Methodology}

\subsection{Participants}

Participants were 28 preservice teachers ( 27 females and 1 male) at a university's college of education in the southeastern United States. The university is classified by the Southern Association of Colleges and Schools as a Level VI institution and by the Carnegie Foundation for the Advancement of Teaching as Doctoral/Research Intensive University. Age ranges of participants varied as follows: $86 \%$ were $20-29,7 \%$ were $30-39$, and $7 \%$ were 40-49. $89 \%$ of the participants were European American, 3\% were African American, 3\% were Asian American, 
and 3\% did not indicate an ethnicity. All participants were seeking a Class B teaching certificate in Elementary Education. All participants were engaged in coursework and field experiences as part of their teacher preparation program in K-6 Teacher Education.

\subsection{Instrument}

Moore-Hayes $(2008,2011)$ adapted items and a rating scale from research on teacher efficacy conducted by Tschannen-Moran and Woolfolk-Hoy (2001) to create a 5-item instrument for assessing teacher's perceived efficacy beliefs related to technology integration. The resulting survey was used as the data collection instrument in this study. A Likert-type response scale used six points ranging from "not at all" to "a great deal" to obtain individual's perceptions of self-efficacy for technology integration in teaching. A response of 1 indicates the lowest level of perceived self-efficacy on the specific aspect of technology integration addressed by each item whereas a 6 indicates a strong belief that the respondent is well prepared to integrate technology in that particular way.

\subsection{Data Collection and Analysis}

Quantitative, descriptive statistics were used to determine the level of teaching efficacy on technology usage for preservice candidates. After obtaining permission for use, the survey was disseminated via Survey Monkey ${ }^{\mathrm{TM}}$ correspondence to a convenience sample of elementary preservice teachers at the end of their first semester of method's courses ( $68 \%$ of participants) or at the end of their second semester of method's courses (32\% of participants). All of the participants had completed a course specifically designed to teach how to integrate technology as a meaningful learning tool in public school classrooms. To varying degrees, the application of technology as a teaching tool was threaded throughout the method's courses in the K-6 program as well. In addition, the preservice teachers were all placed in classrooms with a moderate level of technological tools available, including SmartBoards, desktop and laptop computers, and hand-held devices. The level of technology use varied by field placement, ranging from the limited use of basic technological tools to enhance lecturing to the in-depth, extensive use of technology for project-based learning.

The research question was examined using descriptive statistics (mean, median, mode, frequencies, and percentages) calculated by converting participants' responses to the five survey items to numerical data. Participation in this survey research was voluntary, and there were no identified risks or benefits nor incentives provided for participation.

\section{Results}

The data were examined to determine the central tendency through the mean, median, and mode in relation to where the data were clustered. Since there were no extreme values in the data set, the mean may be useful in predicting future results. The overall efficacy of the preservice teacher participants regarding their ability to use technology for instructional purposes was a mean of 5.1 on a six-point scale. This indicated a very high level of technological efficacy. In addition, the median number was 5, and the mode was 6 . These descriptive statistics indicated that this group of preservice teachers had a high level of efficacy in their self-perception of using technology as an instructional tool in their teaching. Table 1 presents the mean responses for each item.

Table 1. Preservice teachers' mean response

\begin{tabular}{lc}
\hline Question & M \\
\hline How competent do you perceive yourself to select and use various media to support teaching and learning? & 5.1 \\
How well prepared are you to evaluate software to support teaching and learning? & 4.5 \\
To what extent can you integrate technology across the curriculum? & 5.4 \\
How capable are you of determining why, when, and how to use technology in education? & 5.2 \\
To what extent did you incorporate technology to enhance teaching and learning in the lessons you taught in & 5.4 \\
\hline
\end{tabular}

Note: Based on a Scale from 1 (Not at All) to 6 (A Great Deal)

Question specific data revealed that $68 \%$ of candidates felt a high level of confidence in their ability to select and utilize technology in teaching and learning; however, they felt less confident in their ability to evaluate instructional software with $58 \%$ indicating they were somewhat or a little prepared to do so. Overwhelmingly, $89 \%$ 
of candidates felt they could integrate technology across the curriculum, and $80 \%$ indicated they were capable of determining the why, when, and how to do so most of the time. Additionally, $70 \%$ of candidates reported that their cooperating teacher used technology quite a bit or a great deal, and another $18 \%$ reported the cooperating teacher's use as somewhat. Almost all (93\%) participants indicated that they themselves incorporated technology into the lessons they taught either quite a bit or a great deal.

\section{Discussion}

It is important for educators at all levels to be aware of the impact of self-efficacy related to technology on the learning of their students. Interestingly, preservice teachers in this study had a fairly high efficacy rate on their ability to use technology for instructional purposes. This is important because research supports the impact of teachers' efficacy on teaching and learning (Pajares, Usher, \& Johnson, 2007). Many new teachers have grown up using technology for gaming, social media, and personal research, but not as a teaching tool. Technological tools are now considered a staple in most classrooms as increased availability along with ever-increasing student exposure makes technology's presence in education expected. As societal and educational expectations for using technology in daily classrooms practices continues to rise, it becomes increasingly vital that all educators are sufficiently prepared for this aspect of the teaching profession (Albion, 1999). Thus, teacher education programs must emphasis how to effectively use technology for instructional purposes.

Programs of study in higher education must integrate technology in both coursework and field experiences, to scaffold preservice teachers' through the developmental process of learning to effectively use technological tools as a way to expand students' opportunities for success. As previously noted, positive teacher-efficacy is a necessary stipulation of successful technology incorporation in teaching (Moore-Hayes, 2011). Preservice teachers who observe experienced teachers, in P-12 and university classrooms, successfully integrate technology into learning are more likely to have an increased sense of efficacy (Silverman \& Davis, 2009). Additionally, well-supported preservice teacher mastery experiences lead to positive teaching efficacy and positive learning experiences for public school students while helping prevent unsuccessful experiences that can lead to negative teaching efficacy. . Teacher education programs must ensure that field experiences enhance and apply what preservice teachers learned in the classroom by giving detailed feedback about strengths and weaknesses, so they can reflect upon and learn from both their successes and mistakes (Rohrkemper \& Corno, 1988).

Schrum, Shelly and Miller (2008) advise that it is imperative for universities provide assurance of preservice teachers' adequate preparation to teach with technology, as instructional technology is linked to increased student achievement (Grinager, 2006; Lemke, Coughlin, \& Reifsneider, 2009; Schacter, 1999), helps meet the needs of all learners (Grinager, 2006), and tends to serve as a motivator for students (Campbell \& Jane, 2012; Grinager, 2006; Schacter, 1999). It is essential that teacher preparation programs be designed with technology as foundational to the teaching and learning process rather than as an optional add-on. According to Wang et al. (2004), developing the confidence preservice teachers need to effectively integrate technology within their own classrooms may be supported through the use of electronic vicarious learning experiences. While extensive, intrusive training techniques had no significant effect on elementary teachers' attitude or self-efficacy toward technology (Miles, 2013), successful experiences with instructional technology as a preservice teacher leads to positive efficacy (Flores, 2015; Kramarski, \& Tova, 2015; Shivelya \& Yerrickb, 2014; Silverman \& Davis, 2009), thus, resulting in an increased probability that technology will be used as a teaching tool.

\section{Limitations}

As in all studies, there are some limitations that should be acknowledged. In this study, participants were a convenience sample of elementary teacher candidates from the same university enrolled in a single semester; therefore, the generalizability of the findings are limited. The small sample size of participants also limits the findings to a larger population. Further, participants' demographics may limit generalizability to individuals of different ages, ethnicities, certification areas, and/or educational levels. Additionally, the data collection instrument was a survey, and, though the participants remained anonymous, the self-reporting nature of survey research is a limitation in itself.

\section{Future Research}

Further research using additional data collection measures, such as direct observations and interviews, to triangulate the data and increasing the number of participants would strengthen findings. Designing a study to determine if preservice teachers' technological efficacy was related primarily to coursework, field experiences, or a combination of both would be helpful as preparation programs are designed and refined. It may also be useful to measure preservice teacher efficacy for using technological tools for instruction at various points throughout the program to determine if a change in efficacy exists and if so, what may attribute to that change. Further research 
investigating the effectiveness of various approaches to teacher education and professional development in increasing self-efficacy for teaching with technology is also necessary. Finally, research that connects teachers' technological self-efficacy to the academic achievement and technological self-efficacy of their students would be beneficial.

\section{Conclusion}

Attending to preservice teacher efficacy seems worthy of examination as research points to the fact that the efficacy of experienced teachers is nearly impossible to change (Hoy, 2000). It is important for preservice teachers to graduate with a philosophy that using technology as a teaching tool is integral to everyday teaching and learning. In order for this to occur, they must be taught how to use technology in their lessons while they are in method's courses and provided opportunities to teach utilizing technology in their field experiences. They must be placed in field situations that support the use of instructional technology, with appropriate support from cooperating teachers and field supervisors. The connection between teacher efficacy and student achievement makes it imperative that new teachers graduate with a high sense of self-efficacy regarding their abilities to use technology as an effective teaching tool.

\section{References}

Albion, P. R. (1999). Self-efficacy beliefs as an indicator of teachers' preparedness for teaching with technology. Retrieved from http://eprints.usq.edu.au/6973/1/Albion_SITE_1999_AV.pdf

Bandura, A. (1977). Self-efficacy: Toward a unifying theory of behavioral change. Psychological Review, 84, 191-215. http://dx.doi.org/10.1037/0033-295X.84.2.191

Bandura, A. (1982). Self-efficacy mechanism in human agency. American Psychologist, 37, 122-147. $\mathrm{http}: / / \mathrm{dx}$.doi.org/10.1037/0003-066X.37.2.122

Bandura, A. (1997). Self-efficacy: The exercise of control. New York: W. H. Freeman and Company.

Bitner, N., \& Bitner, J. (2002). Integrating technology into the classroom: Eight keys to success. Journal of Technology and Teacher Education, 70, 95-101.

Campbell, C., \& Jane, B. (2012). Motivating children to learn: The role of technology education. International Journal of Technology and Design Education, 22(1), 1-11. http://dx.doi.org/10.1007/s10798-010-9134-4

Cassidy, S., \& Eachus, P. (2002). Developing the computer user self-efficacy (CUSE) scale: Investigating the relationship between computer self-efficacy, gender and experience with computers. Journal of Educational Computing Research, 26(2), 169-189. http://dx.doi.org/10.2190/JGJR-0KVL-HRF7-GCNV

Cennamo, K. S., Ross, J. D., \& Ertmer, P. A. (2010). Technology integration for meaningful classroom use: A standards-based approach. Belmont, CA: Wadsworth Cengage Learning.

Christensen, R. (1998). Effect of technology integration education on the attitudes of teachers and their students (Unpublished doctoral dissertation). University of North Texas, Denton.

Clausen, J. M. (2007). Beginning teachers' technology use: First-year teachers' development and the institutional context's effect on new teachers' instructional technology use with students. Journal of Research on Technology in Education, 39(3), 245-261. http://dx.doi.org/10.1080/15391523.2007.10782482

Curts, J., Tanguma, J., \& Peña, C. M. (2008). Predictors of Hispanic school teachers' self-efficacy in the pedagogical uses of technology. Computers in the Schools, 25(1), 48-63. http://dx.doi.org/10.1080/07380560802157766

Dembo, M. H., \& Gibson, S. (1985). Teachers' sense of self-efficacy: An important factor in school improvement. The Elementary School Journal, 86, 173-184. http://dx.doi.org/10.1086/461441

Ertmer, P. A. (2005). Teacher pedagogical beliefs: The final frontier in our quest for technology integration? Educational Technology Research and Development, 53(4), 25-39. http://dx.doi.org/10.1007/BF02504683

Flores, I. (2015). Developing preservice teachers' self-efficacy through field-based science teaching practice with elementary students. Research in Higher Education Journal, 27, 1-19.

Gersten, R., Chard, D., \& Baker, S. (2000). Factors enhancing sustained use of research-based instructional practices. Journal of Learning Disabilities, 33, 445-458. http://dx.doi.org/10.1177/002221940003300505

Gibson, S., \& Dembo, M. H. (1984). Teacher efficacy: A construct validation. Journal of Educational Psychology, 76(4), 569-582. http://dx.doi.org/10.1037/0022-0663.76.4.569

Gökçek, T, Güneş, G., \& Gençtürk, E. (2013). Evaluation of primary school teachers' technological self-efficacy. 
International Online Journal of Educational Sciences, 5(1), 42-51.

Graham, S., Harris, K. R., Fink, B., \& MacArthur, C. A. (2001). Teacher efficacy in writing: A construct validation with primary grade teachers. Scientific Studies of Reading, 5, 177-203.

Graham, S., Harris, K. R., Fink, B., \& MacArthur, C. A. (2003). Primary grade teachers' instructional adaptations for struggling writers: A national survey. Journal of Educational Psychology, 95(2), $279-292$. http://dx.doi.org/10.1037/0022-0663.95.2.279

Grinager, H. (2006). How education technology leads to improved student achievement. Retrieved from http://www.ncsl.org/portals/1/documents/educ/item013161.pdf

Groth, L. A., Dunlap, K. L., \& Kidd, J. K. (2007). Becoming technologically literate through technology integration in PK-12 preservice literacy courses: Three case studies. Reading Research and Instruction, 46(4), 363-386. http://dx.doi.org/10.1080/19388070709558476

Handler, M. G. (1993). Preparing new teachers to use computer technology: Perceptions and suggestions for teacher educators. Computers and Education, 20(2), http://dx.doi.org/10.1016/0360-1315(93)90082-T

Haverback, H. R., \& Parault, S. J. (2011). High efficacy and the preservice reading teacher: A comparative study. Teaching and Teacher Education, 27, 703-711. http://dx.doi.org/10.1016/j.tate.2010.12.001

Henson, R. (2002). From adolescent angst to adulthood: Substantive implications and measurement dilemmas in the development of teacher efficacy research. Educational Psychology, 37(3), 137-150. http://dx.doi.org/10.1207/S15326985EP3703_1

Hoy, A. W. (2000). Changes in teacher efficacy during the early years of teaching. Paper presented at the annual meeting of the American Educational Research Association, New Orleans, LA. Retrieved from http://wps.ablongman.com/wps/media/objects/290/297451/changes\%20in\%20efficacy.pdf

Jimoyiannis, A., \& Komis, V. (2006). Exploring secondary education teachers' attitudes and beliefs towards ICT adoption in education. Themes in Education, 7(2), 181-204.

Knoblauch, D. H., \& Hoy, A. W. (2008). "Maybe I can teach those kids." The influence of contextual factors on student teachers' efficacy beliefs. Teaching and Teacher Education, 24(1), 166-179. http://dx.doi.org/10.1016/j.tate.2007.05.005

Kramarski, B., \& Tova M. (2015). Effect of a TPCK-SRL Model on teachers' pedagogical beliefs, self-efficacy, and technology-based lesson design. In C. Angeli, \& N. Valanides (Ed.), Technological pedagogical content knowledge: Exploring, developing, and assessing TPCK (pp. 89-112). NY: Springer. http://dx.doi.org/10.1007/978-1-4899-8080-9_5

Lemke, C., Coughlin, E., \& Reifsneider, D. (2009). Technology in schools: What the research says: An update. Culver City, CA: Commissioned by Cisco.

Lever-Duffy, J., \& McDonald, J. B. (2011). Teaching and learning with technology. Boston, MA: Pearson Education.

Marcinkiewicz, H. R. (1994). Computers and teachers: Factors influencing computer use in the classroom. Journal of Research on Computing in Education, 220-237. http://dx.doi.org/10.1080/08886504.1993.10782088

Miles, G. (2013). How is teacher self-efficacy and attitude toward technology affected by extended intrusive training? Instructional Technology Education Specialist Research Papers. Paper 8. Retrieved from http://digitalcommons.georgiasouthern.edu/edu-papers/8

Moore-Hayes, C. (2008). Teacher efficacy: Exploring preservice and beginning teachers' perceptions of their preparedness to teach (Unpublished doctoral dissertation). Minneapolis, MN: Capella University.

Moore-Hayes, C. (2011). Technology integration preparedness and its influence on teacher-efficacy. Canadian Journal of Learning and Technology, 37(3), 1-15.

National Council of Teachers of English. (2013). The NCTE Definition of $21^{\text {st }}$ Century Literacies: A Position Statement. National Council of Teachers of English. Urbana: IL. Retrieved from http://www.ncte.org/positions/statements/21stcentdefinition

Oliver, T. A., \& Shapiro, E. (1993). Self-efficacy and computers. Journal of Computer-Based Instruction, 20 , 81-85. 
Pajares, M. F. (1992). Teachers' beliefs and educational research: Cleaning up a messy construct. Review of Educational Research, 62(3), 307-332. http://dx.doi.org/10.3102/00346543062003307

Pajares, F. (2002). Overview of social cognitive theory and of self-efficacy. Retrieved from http://www.emory.edu/EDUCATION/mfp/eff.html

Pajares, F., Usher, E. L., \& Johnson, M. J. (2007). Sources of writing self-efficacy beliefs of elementary, middle, and high school students. Research in the Teaching of English, 42(1).

Paraskeva, F., Bouta, H., \& Papagianni, A. (2008). Individual characteristics and computer self-efficacy in secondary education teachers to integrate technology in educational practice. Computers \& Education, 50, 1084-1091. http://dx.doi.org/10.1016/j.compedu.2006.10.006

Pendergast, D., Garvis, S., \& Keogh, J. (2011). Pre-service student-teacher self-efficacy beliefs: An insight into the making of teachers. Australian Journal of Teacher Education, 36(12), 46-57. http://dx.doi.org/10.14221/ajte.2011v36n12.6

Pope, M., Hare, D., \& Howard, E. (2002). Technology integration: Closing the gap between what preservice teachers are taught to do and what they can do. Journal of Technology and Teacher Education, 10, 191-204.

Pope, M., Hare, D., \& Howard, E. (2005). Enhancing technology use in student teaching: A case study. Journal of Technology and Teacher Education, 75, 573-618.

Putman, S. M. (2012). Investigating teacher efficacy: Comparing preservice and inservice teachers with different levels of experience. Action in Teacher Education, 34(1), 26-40. http://dx.doi.org/10.1080/01626620.2012.642285

Roblyer, M. D., \& Doering, A. H. (2010). Integrating educational technology into teaching (5th ed.). Boston: Pearson Education.

Rohrkemper, M., \& Corno, L. (1988). Success and failure on classroom tasks: Adaptive learning and classroom teaching. Elementary School Journal, 88, 297-312. http://dx.doi.org/10.1086/461540

Romiszowski, A. J., \& Ravitz, J. (1997). Computer-mediated communication. In Cr. R. Dilles, \& A. Romiszowksi (Eds.), Instructional developmental paradigms (pp. 745-768). Englewood Cliffs, NJ: Educational Technology Publications.

Ropp, M. M. (1999). Exploring individual characteristics associated with learning to use computers in preservice teacher preparation. Journal of Research on Computing in Education, 31(4), 402-423. http://dx.doi.org/10.1080/08886504.1999.10782262

Schacter, J. (1999). The impact of education technology on student achievement: What the most current research has to say. Retrieved from http://www2.gsu.edu/ wwwche/Milken\%20report.pdf

Schrum, L., Shelly, G., \& Miller, R. (2008). Understanding tech-savvy teachers: Identifying their characteristics, motivation and challenges. International Journal of Technology in Teaching and Learning, 4(1), 1-20. http://dx.doi.org/10.1016/j.compedu.2006.10.006

Shivelya, C. T., \& Yerrickb, R. (2014). A case for examining pre-service teacher preparation for inquiry teaching science with technology. Research in Learning Technology, 22. http://dx.doi.org/10.3402/rlt.v22.21691

Sure, S. (2009). Development of a tool to measure computer self-efficacy of student teachers. Retrieved from $\mathrm{http} / / /$ www.academia.edu/1338238/DEVELOPMENT_OF_A_TOOL_TO_MEASURE_COMPUTER_SEL F-EFFICACY_OF_STUDENT_TEACHERS

Silverman, S., \& Davis, H. (2009). Teacher efficacy. Retrieved from $\mathrm{http}: / / \mathrm{www}$. education.com/reference/article/teacher-efficacy

Sparks, G. M. (1988). Teachers' attitudes toward change and subsequent improvements in classroom teaching. Journal of Educational Psychology, 80, 111-117. http://dx.doi.org/10.1037/0022-0663.80.1.111

Summers, M. (1990). New student teachers and computers: An investigation of experiences and feelings. Educational Review, 42(3), 261-271. http://dx.doi.org/10.1080/0013191900420304

Teo, T. (2009). Modeling technology acceptance in education: A study of pre-service teachers. Computers \& Education, 52(1), 302-312. http://dx.doi.org/10.1016/j.compedu.2008.08.006

Teo, T. (2010). A path analysis of pre-service teachers' attitudes to computer use: Applying and extending the Technology Acceptance Model in an educational context. Interactive Learning Environments, 18(1), 65-79. http://dx.doi.org/10.1080/10494820802231327 
Tschannen-Moran, M., Hoy, A., \& Hoy, K. (1998). Teacher efficacy: Its meaning and measure. Review of Educational Research, 68(2), 202-248. http://dx.doi.org/10.3102/00346543068002202

Tschannen-Moran, M., \& Woolfolk-Hoy, A. (2001). Teacher efficacy: Capturing an elusive construct. Teacher and Teacher Education, 17(7), 783-805. http://dx.doi.org/10.1016/S0742-051X(01)00036-1

Unesco. (2000). Informatics for secondary education. A curriculum for schools. Paris: Unesco.

Wang, L., Ertmer, P. A., \& Newby, T. J. (2004). Increasing preservice teachers' self-efficacy beliefs for technology integration. Journal of Research on Technology in Education, 36(3), 231-250. http://dx.doi.org/10.1080/15391523.2004.10782414

Watson, D. (2006). Understanding the relationship between ICT and education means exploring innovation and change. Education and Information Technologies, 11(3), 199-216. http://dx.doi.org/10.1007/S10639-006-9016-2

Weinstein, C. (1988). Preservice teachers' expectations about the first year of teaching. Teaching and Teacher Education, 4, 31-41. http://dx.doi.org/10.1016/0742-051X(88)90022-4

Wong, B. Y. L. (1997). Clearing hurdles in teacher adoption and sustained use of research-based instruction. Journal of Learning Disabilities, 30, 482-486. http://dx.doi.org/10.1177/002221949703000503

Zhao, Y., \& Frank, K. A. (2003). Factors affecting technology uses in schools: An ecological perspective. American Educational Research Journal, 40(4), 807-840. http://dx.doi.org/10.3102/00028312040004807

Zhao, Y., Tan, S. H., \& Mishra, P. (2001). Teaching and learning: Whose computer is it? Journal of Adolescent \& Adult Literacy, 44(4), 348-355.

\section{Copyrights}

Copyright for this article is retained by the author(s), with first publication rights granted to the journal.

This is an open-access article distributed under the terms and conditions of the Creative Commons Attribution license (http://creativecommons.org/licenses/by/3.0/). 